\title{
HPV16-E2 protein modifies self-renewal and differentiation rate in progenitor cells of human immortalized keratinocytes
}

Victoria Domínguez-Catzín, Alicia-María Reveles-Espinoza, Janet Sánchez-Ramos, Raúl Cruz-Cadena, Diana Lemus-Hernández and Efraín Garrido*

\begin{abstract}
Background: Cervical cancer is the fourth cause of death worldwide by cancer in women and is a disease associated to persistent infection with human papillomavirus (HPV), particularly from two high-risk types HPV16 and 18. The virus initiates its replicative cycle infecting cells located in the basal layer of the epithelium, where a small population of epithelial stem cells is located performing important functions of renewal and maintenance of the tissue. Viral E2 gene is one of the first expressed after infection and plays relevant roles in the replicative cycle of the virus, modifying fundamental processes in the infected cells. Thus, the aim of the present study was to demonstrate the presence of hierarchic subpopulations in HaCaT cell line and evaluate the effect of HPV16-E2 expression, on their biological processes.
\end{abstract}

Methods: HaCaT-HPV16-E2 cells were generated by transduction of HaCaT cell line with a lentiviral vector. The a6-integrin-CD71 expression profile was established by immunostaining and flow cytometric analysis. After sorting, cell subpopulations were analyzed in biological assays for self-renewal, clonogenicity and expression of stemness factors (RT-qPCR).

Results: We identified in HaCaT cell line three different subpopulations that correspond to early differentiated cells (a6-integrin ${ }^{\text {dim }}$ ), transitory amplifying cells (a6-integrin ${ }^{\text {bri }} /$ CD71 $1^{\text {bri }}$ ) and progenitor cells (a6-integrin ${ }^{\text {bri }} / C_{C D 7}{ }^{\text {dim }}$ ). The last subpopulation showed stem cell characteristics, such as self-renewal ability, clonogenicity and expression of the well-known stem cell factors SOX2, OCT4 and NANOG, suggesting they are stem-like cells. Interestingly, the expression of HPV16-E2 in HaCaT cells changed its a6-integrin-CD71 immunophenotype modifying the relative abundance of the cell subpopulations, reducing significantly the percentage of a6-integrin ${ }^{\text {bri }} / C D 71^{\text {dim }}$ cells. Moreover, the expression of the stem cell markers was also modified, increasing the expression of SOX2 and NANOG, but decreasing notably the expression of OCT4.

Conclusions: Our data demonstrated the presence of a small subpopulation with epithelial "progenitor cells" characteristics in the HaCaT cell line, and that HPV16-E2 expression on these cells induces early differentiation.

Keywords: HPV16-E2, Epithelial progenitor cells, HaCaT cells, Self-renewal, Epithelial differentiation, Immunophenotype, Stem cell markers

\footnotetext{
*Correspondence: egarrido@cinvestav.mx

Laboratory of Research in Cancer Molecular and Cell Biology, Department of

Genetics and Molecular Biology, CINVESTAV-IPN, Av. Instituto Politécnico

Nacional 2508, Col. San Pedro Zacatenco, C.P. 07360 México D.F., Mexico
} 


\section{Background}

High risk papillomavirus (HPV16 and 18) have been widely studied due to its association with cervical cancer and tumors of other anogenital sites [1]. These are small un-envolved virus with a circularized double stranded DNA genome, containing eight open reading frames that are expressed either early (E1, E2, E4, E5, E6 and E7) or late (L1 and L2) during the infection, and a noncoding region known as long control region (LCR) which contains the viral early promoter, the enhancer and the origin of replication [2, 3].

The HPV life cycle is intimately linked to epithelial differentiation [1]. HPV normally infects dividing cells at the basal layer of the epithelium but completes its life cycle by amplifying progeny DNA genomes in the spinous layer and carrying out viral encapsidation in the uppermost epithelial layer named the granular layer [4].

One of the proteins that plays a crucial role in the papillomaviruses life cycle is the E2 protein. It possesses a DNA-binding domain and a transactivation domain that are linked by a serine-arginine-rich hinge region [5]. E2 as a homodimer binds the cognate sequences ACCGN4CGGT (E2-binding sites [E2BSs]) in the viral LCR, and different experimental systems have shown that it regulates the viral E6 and E7 oncogenes transcription, acting as an activator or as a repressor depending on the protein levels and the specific sites contacted $[6,7]$. However, the evidence points to a repressive function of E2 in controlling the viral early promoter [8]. On the other hand, another important role of E2 is to participate as an auxiliary replication factor, since at the origin of DNA replication, E2 interacts with and loads the HPV E1 replication helicase, recruiting then the cellular DNA replication machinery [8-11]. E2 also has an crucial role in segregation of viral episomal genomes during the division of infected cells by interacting with chromatin adapter proteins that tether them to host mitotic chromosomes [8].

In addition, possibly by an indirect mechanism involving its interaction with several cellular proteins, the expression of E2 also has an impact on the cellular transcription profile, affecting the expression of genes involved in key processes such as proliferation, differentiation, apoptosis and senescence [12-20].

The biological effects of E2 on mammalian cells have been generally studied using transiently transfected cancer cell lines. Early studies in HPV-positive cervical carcinoma derived cell lines [21], indicated that transient overexpression of E2 induces apoptosis in these cells due to repression of endogenous E6/E7 expression [22-27]. However, also in HPV negative cells, E2 overexpression induces apoptosis by both transactivation independent and mediated through activation of caspase $8[28,29]$. It has been also observed that sustained expression of E2 in HPV positive cells, induces a prolonged growth arrest and induces irreversible senescence [30-33], probably as a default pathway for cells which exit the cell cycle, since most of these cells are incapable of terminal differentiation.

Then, the observed effects of E2 on the processes of apoptosis and senescence could be related to its role in differentiation, since it is well known that a critical step to start this process is an arrest in the cell cycle followed by the expression of genes involved in early differentiation. If these genes are not correctly expressed, cells could keep in an irreversible senescence status and progress later to apoptosis or immortalization programs [34, 35].

Considering the technical difficulty to establish a convenient cellular stratification system to follow step by step the progress of the infection, most of the studies on the effects of HPV gene expression on epithelial differentiation process have been performed on carcinoma derived cell lines [36-38], or immortalized keratinocytes from several tissues [39-41].

In fact, the induction of cell differentiation has been demonstrated in HPV16-E2 stably transfected $\mathrm{HaCaT}$ cells, showing a typical differentiated morphology, cell elongation and multilayer colonies growth, besides the expression of the classical keratinocytes differentiation markers involucrin, filagrin and cytokeratins 1 and 10 [34].

However, since E2 is one of the first expressed genes in the epithelial basal layer during infection [42, 43], the understanding of its effects on early differentiation must be studied on cellular models that mimic this layer in the epithelium, considering the cellular subpopulations that constitute it, including epithelial stem cells.

Different strategies have been used to identify these cells from epithelial derived transformed cell lines and keratinocytes primary cultures, such as the expression of the membrane molecules desmoglein-3 and $\beta 1$ integrin, the nuclear presence of p63, or metabolic characteristics of these cells, such as the over-expression of aldehyde-dehydrogenase enzyme (ALDH) or the ATPbinding cassette subfamily G (ABCG) transporter pump [44-47]. Nevertheless, the simultaneous detection of $\alpha 6-$ integrin (CD49f) and the transferrin receptor CD71 levels has demonstrated in a very confident form a hierarchical organization in keratinocytes primary cultures with the presence of three cellular subpopulations [48].

In the present work, we have taken advantage of the $\alpha 6$ integrin and CD71 detection and cell separation described by Schluter et al. [48], and demonstrated that $\mathrm{HaCaT}$ cell line derived from spontaneously immortalized keratinocytes, where HPV genomes are absent and have been extensively used to simulate epithelial tissues, possess cellular subpopulations with similar characteristics to those from the stratified epithelial basal layer, corresponding to: 
cells in an early differentiation process $\alpha 6$-integrin ${ }^{\text {dim }}$ $(8.16 \pm 0.52 \%)$, transitory amplifying cells $\alpha 6$-integrin ${ }^{\text {bri }}$ / $\mathrm{CD}^{\text {bri }}(87.27 \pm 1.21 \%)$ and progenitor cells $\alpha 6$ integrin $^{\text {bri }} / C D 71^{\operatorname{dim}}(1.16 \pm 0.08 \%)$. This latter subpopulation expressed high mRNA levels of SOX2, NANOG and OCT4 factors, a high self-renewal activity and a high proportion of holoclones formation in clonogenic assays, all of them characteristics of epithelial stem cells.

Besides, we demonstrated that HPV16-E2 expression modifies the relative abundance of these subpopulations, favoring the enrichment of the early differentiated subpopulation in a comparable way than the differentiation processes produced by the induction with retinoic acid (RA) or calcium chloride $\left(\mathrm{CaCl}_{2}\right)$ in these cells.

\section{Methods}

\section{Cell cultures}

HEK293-FT cells from ATCC and HaCaT cells (a generous gift from Dr. Norbert Fusenig) were grown in culture dishes in Dulbecco's modified Eagle's medium (DMEM, Invitrogen, CA, USA) supplemented with $10 \%$ fetal bovine serum (FBS, Gibco, NY, USA), L-glutamine (2 mM), sodium pyruvate $(1 \mathrm{mM})$, penicillin $(50 \mathrm{U} / \mathrm{ml})$, and streptomycin $(50 \mu \mathrm{g} / \mathrm{ml})$. Both cell lines were incubated in a humidified atmosphere with $5 \% \mathrm{CO}_{2}$ at $37{ }^{\circ} \mathrm{C}$ and maintained in exponential growth phase.

\section{Lentiviral generation}

A lentiviral system containing a cassette for puromycin selection and the transgene expression controlled by the promoter for the elongation factor $1-\alpha$ (EF1- $\alpha)$, was used in this work. The E2 gene from HPV16 was amplified by PCR with the forward (Fw) primer 5' ATTCCG AATTCATGGAGACTCT $3^{\prime}$ and the reverse (Rev) primer 5' TTCGGGATCCTCATATAGACAT 3', using as a template the plasmid pcDNA3-E2. The corresponding amplicon was cloned in the pSin-EF2-Pur plasmid (Addgene, MA, USA) using the EcoRI and BamHI restriction sites, generating the vector pSin-EF2-E216-Pur. A pSin-EF2-Vac-Pur vector was also built, incorporating the EcoRI-BamHI fragment from the pSin-EF2-Pur plasmid. This vector $\mathrm{pSin}-\mathrm{EF} 2-\mathrm{Vac}-\mathrm{Pur}$ allowed us to generate a lentivirus that does not contain expression cassette, denominated Lenti-Vac. Lentivirus were generated by cotransfection of the corresponding pSin-EF2-X-Pur with pMD2.G and psPAX2 plasmids into packing HEK293FT cells using Lipofectamine Transfection Reagent (Invitrogen, CA, USA) during $24 \mathrm{~h}$. After $48 \mathrm{~h}$ transfection, the supernatant from the cell cultures were ultracentrifugated $(25,000 \mathrm{rpm}$ in SW41 Ti rotor) for 2 $\mathrm{h}$ at $4{ }^{\circ} \mathrm{C}$, to purify the lentiviral particles. The pellets were suspended in cold phosphate buffer saline (PBS) containing $0.01 \%$ bovine serum albumin (BSA) and stored at $-70{ }^{\circ} \mathrm{C}$.

\section{Lentiviral transduction}

$2.5 \times 10^{5} \mathrm{HaCaT}$ cells were seeded in DMEM with $10 \%$ SFB $24 \mathrm{~h}$ before the infection. The cell cultures were then incubated with $1 \mathrm{MOI}$ (multiplicity of infection) of either HPV16-E2 lentivirus or Lenti-Vac for $24 \mathrm{~h}$ in DMEM with $10 \%$ SFB and polybrene $(8 \mu \mathrm{g} / \mathrm{ml})$, in order to allow virus adsorption. The viral stock was then removed away and $48 \mathrm{~h}$ post-infection the puromycin (Sigma-Aldrich, MO, USA) selection $(0.45 \mu \mathrm{g} / \mathrm{ml})$ was started.

\section{RNA extraction and gene expression analysis}

Total RNA was extracted from cells using the TRIzol method, treated with RQ1 DNase (Promega, WI, USA) for $2 \mathrm{~h}$ at $37{ }^{\circ} \mathrm{C}$ and $2 \mu \mathrm{g}$ of RNA were reverse transcribed into cDNA using the enzyme M-MLV RT at $42{ }^{\circ} \mathrm{C}$ and Oligo-dT 15 (Promega, WI, USA).

To determinate the transduction and the transgene expression, we amplify by PCR a 250 bp fragment of the HPV16-E2 gene, using primers Fw: 5' TTGGGG ATCCGTGTTTAGCAGCAACGAAGTAT 3' and Rev: 5' ATCCGAATTCTCAGTTAATCCGTCCTTTGTGT GAGCT 3'. HPV16-E2 expression in transduced cells was monitored daily.

To evaluate the mRNA expression of the stem cells markers we performed Real-Time PCR (qPCR) using the ABsolute qPCR SYBR Green Mix (Thermo Scientific, PA, USA) and an ABI StepOnePlus Real-Time PCR System, using the following primers: SOX2 Fw: 5' TCA GGAGTTGTCAAGGCAGAG 3', Rev: 5' AGAGGCAA ACTGGAATCAGGA 3'; NANOG Fw: 5' GCAATGGT GTGACGCAGAAG 3', Rev: 5' ATTGGAAGGTTCCC AGTCGG 3'; OCT4 Fw: 5' CTTCGCAAGCCCTCA TTTCACC 3', Rev: 5' GGTCCGAGGATCAACCCAG $3^{\prime}$. As a control for endogenous constitutively expressed gene, we used $\beta$-actin Fw: 5' GCGGGAAATCGTGCGT GACATT 3', Rev: 5' GATGGAGTTGAAGGTAGTTT CGTG 3'. Relative quantification values and the cycle thresholds (Cts) for the target amplicon and the endogenous control $(\beta$-actin) were determined for each sample (Total, $\alpha 6$-integrin ${ }^{\text {bri }} / \mathrm{CD} 71^{\mathrm{dim}}$ and Non- $\alpha 6$-integrin ${ }^{\mathrm{bri}} /$ CD71 $\left.{ }^{\text {dim }}\right)$. The value for the target, normalized to the endogenous control for the samples, relative to the value in the total cells was then calculated with the formula ${ }^{\Delta \Delta}$ Ct [49].

\section{Immunoblotting analysis of proteins}

Total cell lysates were prepared from $\mathrm{HaCaT}$ wild type (HaCaTwt) and HaCaT-HPV16-E2 using Bolen-modified RIPA buffer (20 mM MOPS-NaOH pH 7.0, $150 \mathrm{mM}$ $\mathrm{NaCl}, 1 \%$ sodium deoxycholate, $1 \%$ Nonidet P-40, $1 \mathrm{mM}$ EDTA, 0.1\% SDS) and protease inhibitor cocktail (Roche Diagnostics, Basel, Switzerland). Total proteins $(50 \mu \mathrm{g})$ were separated through SDS $10 \%$ polyacrilamide gels 
(SDS-PAGE), transferred to nitrocellulose membranes, and immunoblotted using either specific anti-HPV16-E2, anti-cytokeratin 14 (Santa Cruz Biotecnology Inc., CA, USA), anti-cytokeratin 10 (Abcam PLC, MA, USA) or anti- $\beta$-actin (a generous gift of Dr. Manuel Hernández) monoclonal antibodies. Secondary antibodies peroxidase conjugated AffiniPure goat anti-mouse IgG $(\mathrm{H}+\mathrm{L})$ or peroxidase conjugated AffiniPure goat anti-rabbit IgG $(\mathrm{H}+\mathrm{L})$ (Jackson ImmunoResearch Laboratories, PA, USA) were used. Immunoreaction was developed using the SuperSignal West Pico Chemiluminiscent Substrate (Thermo Scientific, IL, USA) and the proteins were quantified with Image J software (National Institutes of Health, MD, USA).

\section{Flow - cytometric analysis and cell sorting}

$\mathrm{HaCaT}$ cell cultures (lentivirus transduced or wt) were washed twice in PBS, trypsinized, and suspended in icecold PBS containing 2\% FBS/2\% BSA and kept for $15 \mathrm{~min}$ at $4{ }^{\circ} \mathrm{C}$. Cells were pelleted by centrifugation and suspended at $1 \times 10^{6} / 100 \mu \mathrm{l}$ in ice-cold PBS containing $1 \%$ BSA and then processed for single or double staining with PE-Cy5 mouse anti-human CD71 and PE rat anti-human $\alpha 6$ integrin (BD Biosciences, NJ, USA) during $45 \mathrm{~min}$ at $4{ }^{\circ} \mathrm{C}$, using the appropriate negative controls to establish the compensation settings on the FACS. Cells were washed twice with cold PBS, suspended in PBS at $2-3 \times 10^{6} / \mathrm{ml}$, and kept at $4{ }^{\circ} \mathrm{C}$ until their flow-cytometric analysis. Cell sorting was performed using MoFlo XDP flow cytometer (Beckman Coulter, CA, USA).

\section{Self-renewal assay}

$\alpha 6$-integrin ${ }^{\text {bri }} /$ CD71 ${ }^{\text {dim }}$ and Non- $\alpha 6$-integrin ${ }^{\text {bri }} / C D 71^{\text {dim }}$ $\mathrm{HaCaTwt}$ cells sorted after $\alpha 6$-integrin-CD71 staining, were seeded in six-wells plates at $4.5 \times 10^{3}$ cells/well and cultured under standard conditions. After 10 days culture, cells were analyzed for cell surface phenotype ( $\alpha 6$-integrin ${ }^{\text {bri }} /$ CD71 ${ }^{\text {dim }}$ and Non- $\alpha 6$-integrin ${ }^{\text {bri }} /$ CD71 ${ }^{\text {dim }}$ ) and sorted at subsequent passage for another cycle of 10 days to evaluate the self-renewal capacity.

\section{Colony heterogeneity assay}

$\alpha 6$-integrin ${ }^{\text {bri }} / \mathrm{CD} 71^{\text {dim }}$ and Non- $\alpha 6$-integrin ${ }^{\text {bri }} / C D 71^{\text {dim }}$ HaCaTwt cells sorted after $\alpha 6$-integrin-CD71 staining, were seeded in six-wells plates at $4.5 \times 10^{3}$ cells/well and cultured under standard conditions. After 7 days culture, the morphology of the clones (classified as holoclones and paraclones) was observed and counted under an inverted light microscope evaluating the percentage of each type of clone.

\section{Differentiation analysis}

HaCaTwt cells were seeded and cultured under standard conditions during $24 \mathrm{~h}$. The cell cultures were then washed twice with $\mathrm{PBS}$ and incubated with complete media containing $\mathrm{CaCl}_{2} 5 \mathrm{mM}$ or RA $1 \mu \mathrm{M}$ (Sigma-Aldrich, $\mathrm{MO}$, USA) during additional 5 days. Then cells were harvested and lysates prepared for the analysis of epithelial differentiation markers.

HaCaTwt and HaCaT-HPV16-E2 were treated with $\mathrm{CaCl}_{2}$ or RA as above indicated. After that, the cells were harvested and analyzed by flow cytometry for the $\alpha 6$-integrin-CD71 cell surface phenotype, in order to compare the differentiation status in $\mathrm{HaCaTwt}$ and HaCaT-HPV16-E2.

\section{Statistical analysis}

Data were analyzed using GraphPad Prism v6.0 (GraphPad Software). Results represent the mean of at least three independent experiments; bar \pm standard deviation (SD). An ANOVA test was used to determine the statistical significance of differences in values between two groups. Statistical significance was defined as $p$ value $<0.05$.

\section{Results}

Identification of a "stem-like" subpopulation in HaCaT cell line

To demonstrate the presence of a "progenitor" subpopulation in $\mathrm{HaCaT}$ cell line, we analyzed the cells using the technique described for Schluter et al. [48]. Representative results from the flow-cytometric analyses are shown in Fig. 1 panel a. The HaCaT cell line in our culture conditions presented a profile of three subpopulations with different immunophenothypes: $\alpha 6$-integrin ${ }^{\mathrm{dim}}(8.16 \pm 0.52 \%)$ (R8) that correspond to "early differentiated cells", $\alpha 6$ integrin $^{\text {bri }} / C D 71^{\text {bri }}(87.27 \pm 1.21 \%)$ (R7) corresponding to "transitory amplifying cells" and $\alpha 6$-integrin ${ }^{\text {bri }} / C D 71^{\text {dim }}$ as a minor subpopulation $(1.16 \pm 0.08 \%)$ (R6) apparently corresponding to "progenitor" cells. To corroborate the biological characteristics of these cellular subpopulations, we performed a self-renewal assay sorting the cells after anti- $\alpha 6$-integrin-CD71 staining by flow cytometry and reseeding in separated wells cells from the $\alpha 6$-integrin ${ }^{\text {bri } /}$ CD71 ${ }^{\mathrm{dim}}$ subpopulation and a mix of cells from the $\alpha 6$ integrin $^{\text {bri }} / C D 71^{\text {bri }}$ and $\alpha 6$-integrin ${ }^{\text {dim }}$ subpopulations (Non- $\alpha 6-i n t e g r i n^{\text {bri }} / \mathrm{CD} 71^{\mathrm{dim}}$ ), and evaluated their capacity to regenerate the normal immunophenotypes of the cultures, enrichment ability and colony morphology in clonogenic assays.

$\alpha 6$-integrin ${ }^{\text {bri }} / \mathrm{CD} 71^{\mathrm{dim}}$ restored the immunophenotype of the total cell population in each cycle of sorting and reseeding, and after two rounds the percentage of this subpopulation increased from $2.8 \pm 0.54 \%$ to $3.9 \pm 0.33 \%$ (Fig. 1 , panels $a$ and $b)$. The reseeding of the Non- $\alpha 6$-integrin ${ }^{\text {bri } /}$ $\mathrm{CD}^{\mathrm{dim}}$ was unable to restore the immunophenotype of 


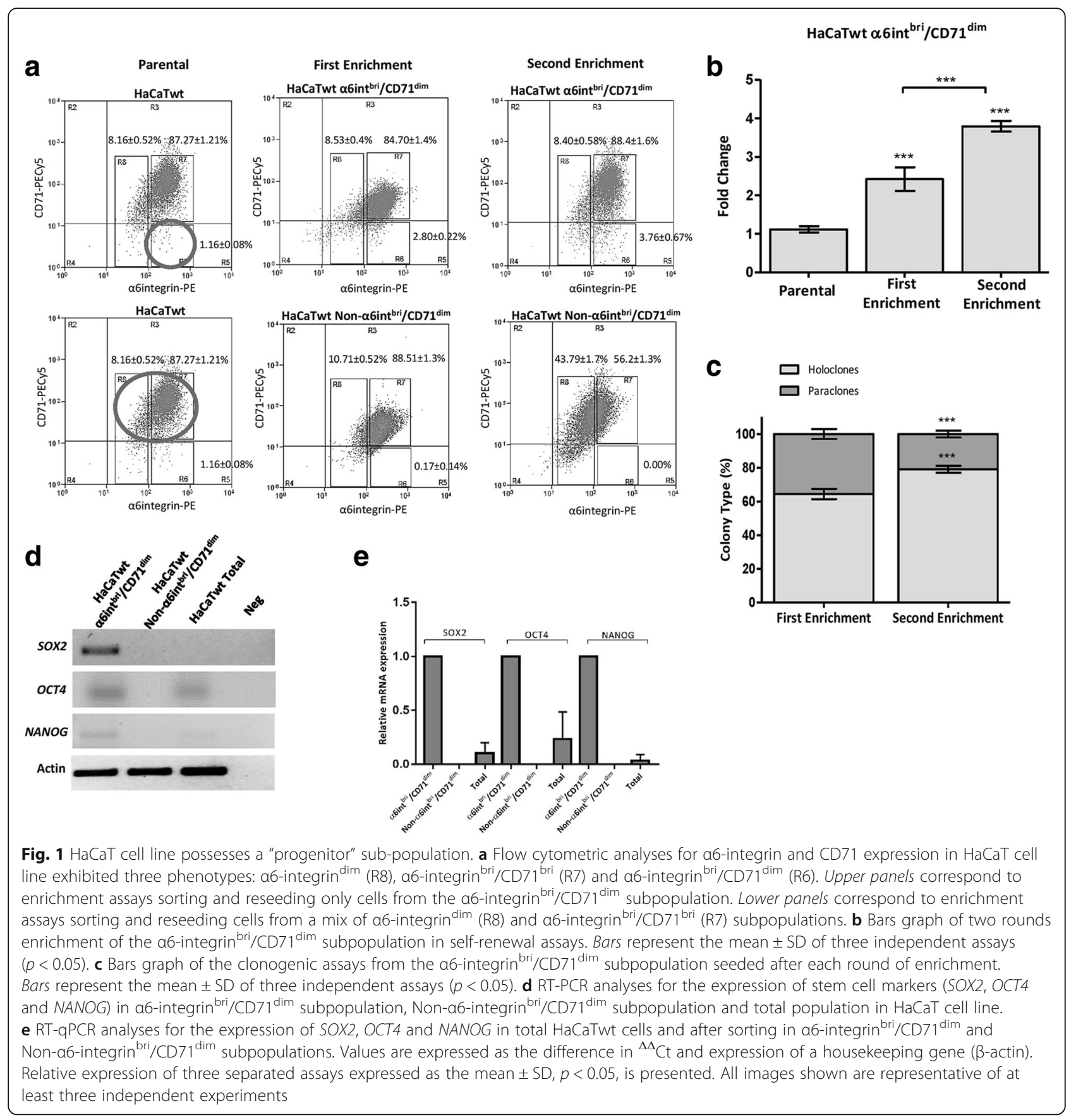

the total population, generating only Non- $\alpha 6$-integrin ${ }^{\text {bri }}$ / $\mathrm{CD}^{\mathrm{dim}}$ (Fig. 1 panel a and Additional file 1: Table S1). Moreover, in the clonogenic assay the percentage of holoclones derived from the $\alpha 6$-integrin ${ }^{\text {bri }} / C D 71^{\mathrm{dim}}$ after sorting and reseeding was considerably higher than those with paraclone morphology in both enrichment assays $(62 \pm 2 \%$ vs $38 \pm 3.5 \%$ and $68 \pm 5.5 \%$ vs $32 \pm 3.5 \%)$ (Fig. 1, panel c), while as expected for more differentiated cells, the clone morphology observed after reseeding the Non- $\alpha 6$-integrin ${ }^{\text {bri }} / C D 71^{\mathrm{dim}}$, was mostly paraclones
( $2 \%$ vs $98 \pm 1 \%$ and $0 \%$ vs $100 \%$ ). Finally, the mRNA evaluation of three of the most important stemness factors (SOX2, NANOG and OCT4) in the different subpopulations isolated by sorting after anti- $\alpha 6$-integrin-CD71 staining and flow-cytometry (Fig. 1, panels d and e), indicated that these genes are expressed in high levels in the $\alpha 6$-integrin ${ }^{\text {bri }} / C D 71^{\text {dim }}$ subpopulation but not in Non- $\alpha 6$-integrin ${ }^{\text {bri }} / C D 71^{\mathrm{dim}}$. These results demonstrate that $\mathrm{HaCaT}$ cell line contains a small "progenitor" cell subpopulation. 
HPV16-E2 protein modifies a6-integrin-CD71 immunophenotype in $\mathrm{HaCaT}$ cell line

It has been shown that HPV-E2 protein can modulate several cellular processes, including apoptosis, proliferation and cell differentiation. In order to evaluate the effect of the expression of this viral protein on $\alpha 6$-integrinCD71 phenotype of $\mathrm{HaCaT}$ cell line, we used a lentiviral vector that efficiently transduce cells from epithelial origin, but also possess the EF1- $\alpha$ promoter that results in a high level of transcription of the incorporated transgene, even in quiescent cells. After transduction of $\mathrm{HaCaT}$ cell line cultures, with Lenti-HPV16-E2 or Lenti-Vac, we confirmed the expression of the transgene in the correspondent cultures HaCaT-HPV16-E2 and HaCaTVac 5 days post-infection, obtaining mRNA and analyzing by RT-PCR (Fig. 2, panel a). Additionally, we obtained total protein extracts and determined the presence of HPV16-E2 protein by SDS-PAGE and western blot, using commercial antibodies (Fig. 2, panel b). As expected, HPV16-E2 mRNA and protein was only detected in the HaCaT-HPV16-E2 transduced cell lines.

The flow-cytometric analysis for immunophenotype of $\alpha 6$-integrin and CD71 staining of the transduced $\mathrm{HaCaT}$ cultures (Fig. 2, panel c) showed evident changes in the relative abundance of the three subpopulations that constitutes this cell line, when HPV16-E2 is expressed. We observed a clear increase in the early differentiated cells $\left(\alpha 6\right.$-integrin $\left.{ }^{\mathrm{dim}}\right)$ passing from $8.16 \pm 0.52 \%$ to $54 \pm 1.34 \%$, while the stem-like subpopulation ( $\alpha 6$-integrin ${ }^{\text {bri }} / \mathrm{CD} 71^{\mathrm{dim}}$ ) decreased from $1.16 \pm 0.08 \%$ to $0.55 \pm 0.06 \%$, suggesting that the expression of this viral gene stimulates the early differentiation in $\mathrm{HaCaT}$ cell line. To discriminate a possible effect of the lentiviral vector on the $\alpha 6$-integrinCD71 phenotype in this cell line, we also compared this phenotype of Lenti-Vac infected cells against that one from non-infected cells, observing that infection with this control virus does not change the subpopulations profile of $\mathrm{HaCaT}$ cell line.

\section{HPV16-E2 protein modifies the expression of "stemness" factors in $\mathrm{HaCaT}$ cell line}

Considering the clear reduction (almost 50\%) in the relative abundance of the $\alpha 6$-integrin ${ }^{\text {bri }} / C D 71^{\text {dim }}$ subpopulation in the $\mathrm{HaCaT}$ cell line induced by HPV16E2 expression, we evaluated the effect of the expression of this viral protein on the mRNA level of several key stemness factors. HaCaT cells were either transduced with Lenti-HPV16-E2 or Lenti-Vac, after 5 days were stained with anti- $\alpha 6$ integrin-CD71 antibodies and isolated by flow-cytometric sorting the $\alpha 6$-integrin ${ }^{\text {bri }}$ / CD71 ${ }^{\text {dim }}$ and Non- $\alpha 6$-integrin ${ }^{\text {bri }} /$ CD71 ${ }^{\text {dim }}$ subpopulations from HaCaT-HPV16-E2, HaCaT-Vac and HaCaTwt. mRNA from each subpopulation was obtained and the expression of SOX2, OCT4 and NANOG genes analyzed by RT-qPCR (Fig. 3). As we expected, the Lenti-Vac transduction does not modified the relative expression of
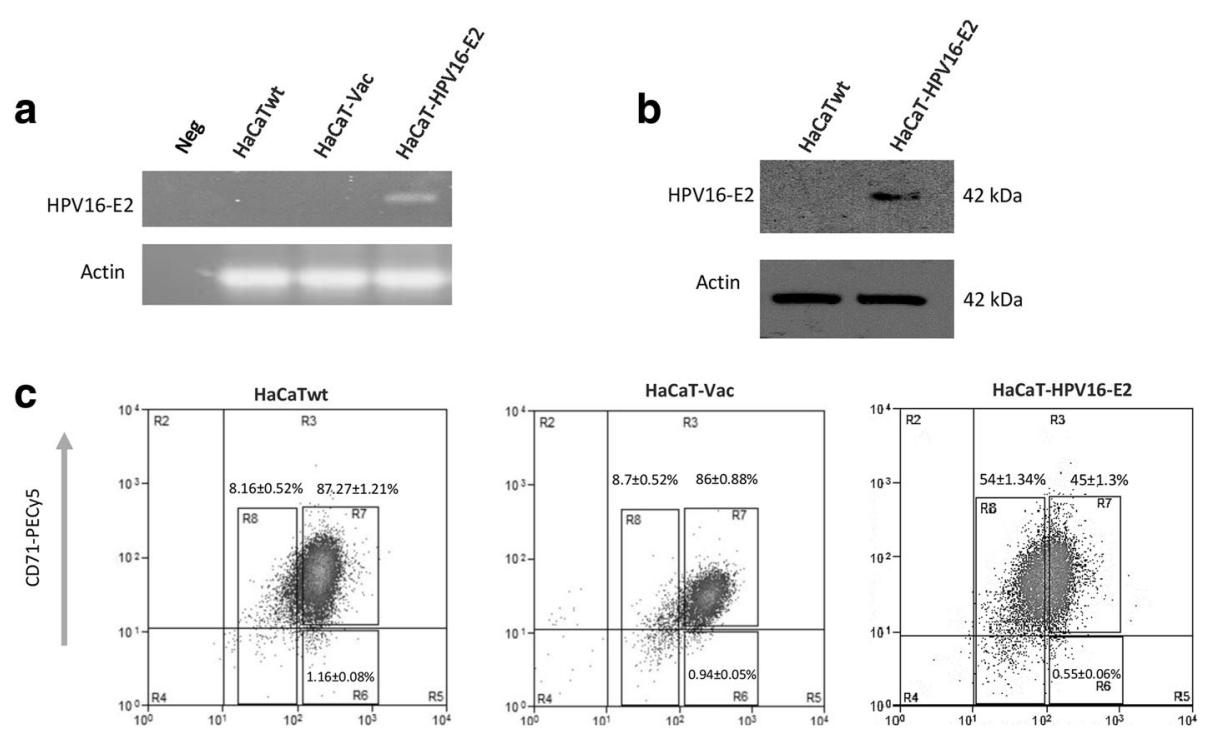

a6integrin-PE

Fig. 2 HPV16-E2 expression modifies the a6-integrin-CD71 subpopulations profile in HaCaT cell line. a RT-PCR analysis of lentivirus transduced HaCaT cells 5 days post-infection. HPV16-E2 is expressed only in transduced cells HaCaT-HPV16-E2. b Western blot analysis showing the expression of HPV16-E2 protein only in the transduced HaCaT-HPV16-E2 cells. c Representative flow cytometry analysis for the a6-integrin-CD71 subpopulations profile in HaCaT-HPV16-E2 cells. R6 decreases almost 50\% while R8 increases at least 5 times in these cells. All images shown are representative of at least three independent experiments 


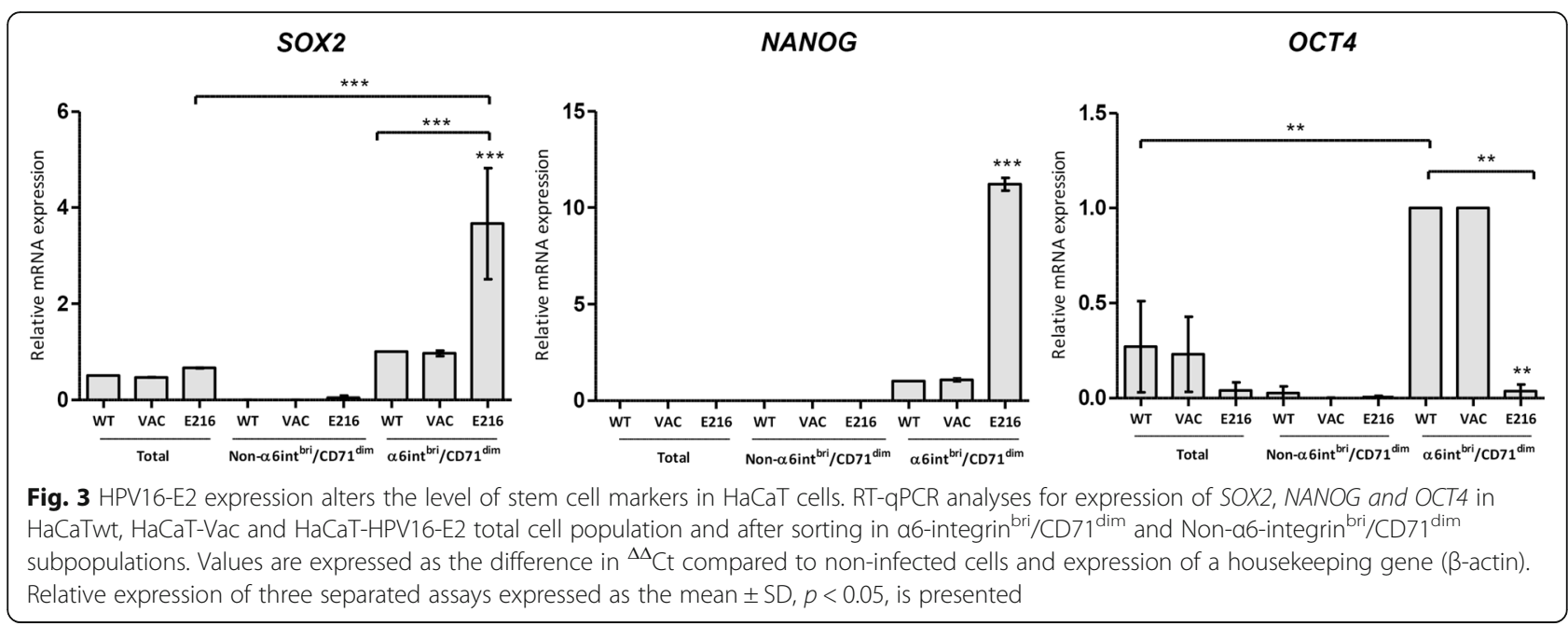

SOX2, NANOG or OCT4 in neither of the HaCaT cell subpopulations; nevertheless, in $\alpha 6$-integrin ${ }^{\text {bri }} / C D 71^{\text {dim }}$ subpopulation from $\mathrm{HaCaT}$ cells expressing HPV16-E2 the mRNA level of SOX2 and NANOG was increased dramatically (5 and 10 times respectively), compared with the level observed in the $\alpha 6$-integrin ${ }^{\text {bri }} / \mathrm{CD} 71^{\mathrm{dim}}$ subpopulation in $\mathrm{HaCaTwt}$ cells. Interestingly, the effect of HPV16-E2 on OCT4 expression was in the opposite way, since the mRNA levels detected for this factor in the $\alpha 6$-integrin ${ }^{\text {bri }} / C D 71^{\text {dim }}$ subpopulation from HaCaT-HPV16-E2 were considerably lower $(0.2$ times) than the observed in the HaCaTwt $\alpha 6$ integrin $^{\text {bri }} / \mathrm{CD} 71^{\mathrm{dim}}$ subpopulation.

All these changes in the expression of stemness factors induced by E2 in the $\alpha 6$-integrin ${ }^{\text {bri }} / \mathrm{CD} 71^{\mathrm{dim}}$ subpopulation, suggest that this viral protein in $\mathrm{HaCaT}$ could be regulating the fate of the cells either to keeping in a stemness status or the exit of these "progenitor" cells to a more differentiated status.

\section{HPV16-E2 protein induces early differentiation in $\mathrm{HaCaT}$ cell line}

The increase observed in the $\alpha 6$-integrin ${ }^{\mathrm{dim}}$ subpopulation in HaCaT-HPV16-E2 cells, strongly suggest that expression of the viral protein induces the cells to differentiation. Then we decided to confirm this, first analyzing the relative levels of cytokeratin 14, a protein expressed in all the constituent cells of the epithelial basal layer [50], and cytokeratin 10, a protein expressed de novo by early differentiated cells [50,51]. Considering the well known effects of differentiation induced on $\mathrm{HaCaT}$ cells by $\mathrm{CaCl}_{2}$ and RA treatments, we exposed $\mathrm{HaCaTwt}$ cells to either $5 \mathrm{mM} \mathrm{CaCl}_{2}$ or $1 \mu \mathrm{M}$ RA for 5 days and used as a reference to compare the expression level of both cytokeratins in HaCaT-HPV16-E2 cells, by western blot analysis. We observed in HaCaT-HPV16-E2 cells a considerable lower level of cytokeratin 14 and more than twice level of cytokeratin 10, compared to HaCaTwt (Fig. 4, panel a). This clearly demonstrates that HPV16-E2 protein promotes early differentiation in $\mathrm{HaCaT}$ cells. Although $\mathrm{CaCl}_{2}$ or RA treatments induced in $\mathrm{HaCaTwt}$ cells a decrease in the protein levels of cytokeratins 14 and 10, the diminution caused by RA was more significant provoking a reduction of $80 \%$ in cytokeratin 14 and $100 \%$ in cytokeratin 10 protein levels, while the decrease observed with $\mathrm{CaCl}_{2}$ treatment was 10 and $60 \%$ respectively (Fig. 4, panel a). These results indicate that both treatments induce cell differentiation in a faster way and probably by a different pathway than HPV16$\mathrm{E} 2$, since the low level of cytokeratin 10 in exposed cells suggest they are in a later step in the cell differentiation process, as has been demonstrated in several reports $[52,53]$.

Having in mind that the effects of these differentiation inducers on the $\alpha 6$-integrin-CD71 subpopulations profile has not been reported, we exposed $\mathrm{HaCaT}$ cultures to either $\mathrm{CaCl}_{2}$ or RA as described above and analyzed the subpopulations profile obtained by flow cytometry from the $\alpha 6$-integrin-CD71 stained cells. We observed that both, $\mathrm{CaCl}_{2}$ and $\mathrm{RA}$ treatments induced significant changes in the $\alpha 6$-integrin-CD71 subpopulations profile in $\mathrm{HaCaT}$ cell line; however clear differences between them were observed suggesting that induction of differentiation with each one of these agents is not equivalent. The main difference observed was that while $\mathrm{CaCl}_{2}$ induced a considerable enrichment in the early differentiated cells ( $\alpha 6$-integrin ${ }^{\text {dim }}$ subpopulation) $(32.51 \pm 1.15 \%)$ (Fig. 4, panel d), the enrichment induced by RA treatment in this subpopulation was even higher $(66.64 \pm 1.5 \%)$ (Fig. 4, panel f).

Considering that cells can naturally receive extracellular stimulus for differentiation independently of the HPV16-E2 expression, we exposed HaCaT-HPV16-E2 cells to either, $\mathrm{CaCl}_{2}$ or RA treatments for 5 days and 

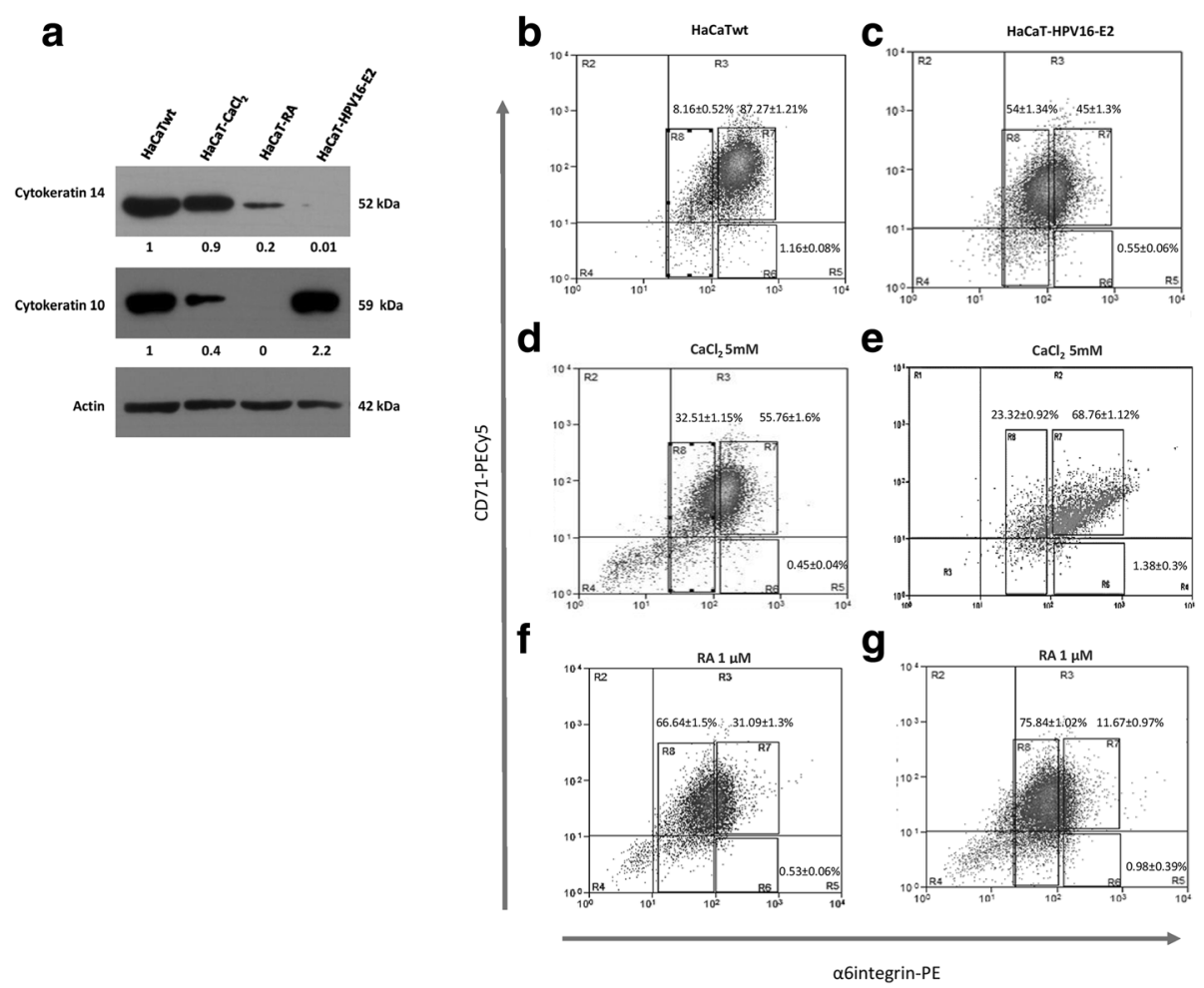

Fig. 4 HPV16-E2 protein promotes differentiation in HaCaT cells in a comparable way than epithelial differentiation inducers. a Western blot

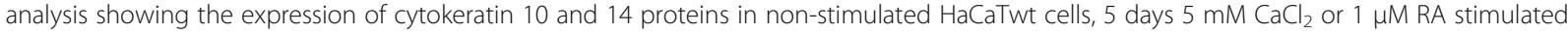
HaCaTwt cells, and HaCaT-HPV16-E2 cells. Numeric values below each lane are the quantitation results expressed as the ratio to non-stimulated HaCaTwt cells and normalized against $\beta$-actin. Flow - cytometric analysis. Left panels (b, $\mathbf{d}$ and $\mathbf{f}$ ), HaCaTwt cells; right panels (c, e and $\mathbf{g})$, HaCaTHPV16-E2 cells. $\mathbf{b}$ and $\mathbf{c}$, non-stimulated cells; $\mathbf{d}$ and $\mathbf{e}, \mathrm{CaCl}_{2}$ stimulated cells; $\mathbf{f}$ and $\mathbf{g}$, RA stimulated cells. All images shown are representative of at least three independent experiments

evaluated the subpopulations profile obtained by flow cytometry from $\alpha 6$-integrin and CD71 stained cells. Interestingly the subpopulation profile generated was particular for each differentiation inducer agent used. In HaCaT-HPV16-E2, $\mathrm{CaCl}_{2}$ treatment induced a considerable increase in the relative abundance of the $\alpha 6$ integrin $^{\text {bri }} / C D 71^{\mathrm{dim}}$ subpopulation $(0.55 \pm 0.06 \%$ vs $1.38 \pm$ 0.3\%) (Fig. 4, panels c and e [R6]), reaching even higher amounts than the percentage of cells present in this subpopulation in $\mathrm{HaCaTwt}$ cultures $(1.16 \pm 0.08 \%)$ (Fig. 4 , panel b). Furthermore, this treatment also induced an increase in the relative abundance of the $\alpha 6$-integrin ${ }^{\text {bri }} /$ $\mathrm{CD}_{71}{ }^{\text {bri }}$ subpopulation, considered transitory amplifying cells ( $45 \pm 1.3 \%$ vs $68.76 \pm 1.12 \%$ ). This suggests that $\mathrm{CaCl}_{2}$ treatment restricts HPV16-E2 expressing cells to a differentiation state still able to proliferate actively (Fig. 4, panels $c$ and e [R7]).

By the other side, RA treatment induced in $\mathrm{HaCaT}$ HPV16-E2 cells an even more marked effect on the differentiation status than on $\mathrm{HaCaTwt}$ cells, leading cells mostly to early differentiation, since the relative abundance of the $\alpha 6$-integrin ${ }^{\text {dim }}$ subpopulation observed was a little higher $(66.64 \pm 1.5 \%$ vs $75.84 \pm 1.02 \%)$
(Fig. 4, panels $\mathrm{f}$ and $\mathrm{g}$ [R8]) in HaCaT-HPV16-E2 cells. In a similar way than the observed in $\mathrm{CaCl}_{2}$ treated $\mathrm{HaCaT}$ HPV16-E2 cells, RA also increased visibly the relative abundance of the $\alpha 6$-integrin ${ }^{\text {bri }} / C D 71^{\mathrm{dim}}$ subpopulation, compared with non-treated HaCaT-HPV16-E2 cells $(0.55$ $\pm 0.06 \%$ vs $0.98 \pm 0.39 \%$ ) (Fig. 4, panels c and g [R6]).

These results suggest that HPV16-E2 protein presence modifies cellular mechanism inducing the early differentiation of the $\alpha 6$-integrin ${ }^{\text {bri }} / \mathrm{CD} 71^{\mathrm{dim}}$ subpopulation in the $\mathrm{HaCaT}$ cell line.

\section{Discussion}

HPV infection in the basal epithelial layer may occur in any cellular type that integrates this layer and then the expression of the early genes, E2 one of the most important in this virus, could have particular effects on each one of the constituent cell types. A limited number of cells in this epithelial layer, possess cell progenitor characteristics and this small subpopulation has been identified and isolated from primary cultures and transformed cell lines by using different experimental approaches such as detection of desmoglein-3, $\alpha 6$ - and $\beta 1$-integrins, CD71, the expression 
and nuclear presence of p63, or the metabolic activity of ALDH or ABCG transporters in these cells [44-47].

$\mathrm{HaCaT}$ cell line that derives from spontaneously immortalized keratinocytes has been widely used to simulate epithelial tissues [54, 55]. Using the method described by Schluter and cols. [48], in this work we demonstrated for the first time that cultures of the $\mathrm{HaCaT}$ cell line, similarly to the reported in keratinocytes primary cultures, contain cellular subpopulations, based on the identification and simultaneous detection of the membrane receptors $\alpha 6$-integrin and CD71, corresponding to: early differentiated cells ( $\alpha 6$-integrin ${ }^{\text {dim }}$ ), transitory amplifying cells ( $\alpha 6$-integrin ${ }^{\text {bri }} / \mathrm{CD} 71^{\text {bri }}$ ) and progenitor cells ( $\alpha 6$-integrin ${ }^{\text {bri }} / C D 71^{\text {dim }}$ ) (Fig. 1, panel a).

Self-renewal assays, clonogenicity and expression of the transcription factors NANOG, SOX2 and OCT4 have been currently used to demonstrate the stemness of putative progenitor cell populations, no matter the method used for its isolation, either based on metabolic characteristics or expression level of specific membrane proteins $[45,56-58]$.

The self-renewal capability observed in cells from the a6-integrin ${ }^{\text {bri }} / \mathrm{CD}{ }^{\mathrm{dim}}$ subpopulation in $\mathrm{HaCaT}$ cells reported in this work, was similar to that reported in several works in the identification of both adult normal and cancer stem cells, where the isolated progenitor subpopulation was also able to reestablish the initial phenotype of the total population, increasing also the number of putative "progenitor" cells after each cycle of separation $[46,59,60]$. However, in a clear contrast with cancer stem cells, putative progenitor cell population in $\mathrm{HaCaT}$ was considerably lower and its enrichment after reseeding was not exponential.

The ability of cells from the $\alpha 6$-integrin ${ }^{\text {bri }} / \mathrm{CD} 71^{\mathrm{dim}}$ subpopulation to form in clonogenic assays mostly holoclones (Fig. 1, panel c), in a similar way than the reported in keratinocytes primary cultures [59], suggest also that cells from this subpopulation have properties of progenitor epithelial cells.

The presence of mRNA from transcription factors SOX2, NANOG and OCT4 (Fig. 1, panels d and e), whose expression has been reported for progenitor cells in normal keratinocytes [56, 61], only in the $\alpha 6$ integrin $^{\text {bri }} / \mathrm{CD} 71^{\mathrm{dim}}$ subpopulation of $\mathrm{HaCaT}$ cells, largely explains its self-renewal capability and the formation mainly of holoclones. In agreement with our results, a recent work reported the immunodetection of NANOG and OCT4 proteins in HaCaT cell line growing in monolayer conditions, despite in those particular culture conditions and unlike than the cancer stem cells evaluated in that work, $\mathrm{HaCaT}$ cells were not capable to form spheroids [45]. Taken together these results confirm that $\alpha 6$-integrin ${ }^{\text {bri }} / C D 71^{\mathrm{dim}}$ subpopulation that constitutes approximately $1 \%$ of the total population in $\mathrm{HaCaT}$ cell line, is enriched in progenitor cells.

Although $\mathrm{HaCaT}$ is an immortalized cell line, it possesses particular characteristics that make it very attractive to be used as biological system, such as the absence of viral sequences in its genome, and its ability to respond to a variety of differentiation stimuli such as $\mathrm{CaCl}_{2}$, RA and cell-cell contact [62-64]. Our demonstration that this cell line possesses, in a low but constant proportion, a cellular subpopulation that express stemness markers, with self-renewal capability similar to the observed in normal epithelial stem cells, constitutes an additional property that must be exploited in this cell line. Then, $\mathrm{HaCaT}$ cell line would seem to be a very appropriate model to study the effects of viral gene expression on the three main subpopulations that constitute the epithelial basal layer and that can be target for the HPV infection.

We observed that expression of HPV16-E2 in HaCaT cells generated a significant change in the proportion of the three cellular subpopulations, possibly favoring the early differentiation, since the relative abundance of progenitor ( $\alpha 6$-integrin ${ }^{\text {bri }} / C D 71^{\mathrm{dim}}$ ) cells decreased notably, while cell subpopulation committed to differentiation $\left(\alpha 6\right.$-integrin ${ }^{\text {bri }}$ ) increased (Fig. 2, panel c). These results confirm and complement the observed by Burns and cols., whom reported the expression of early differentiation markers in the total population of $\mathrm{HaCaT}$ cells expressing HPV16-E2 [34]. In the same way, previous reports from our research group in $\mathrm{C}-33 \mathrm{~A}$ cells, indicated that the presence of HPV16-E2 modifies the gene expression profile affecting importantly several signaling pathways, such as integrins, WNT/ $\beta$-catenin, RhoA and Notch [20], all of them relevant for proliferation and cell differentiation responses.

Although the stem like properties of the $\mathrm{HaCaT}$ HPV16-E2 cells might not change drastically, some aspects of stemness, such as SOX2, NANOG and OCT4 expression are altered. Then, changes in the relative abundance of the subpopulations could be just another effect of the expression of HPV16-E2, considering that our interpretation is based exclusively on the expression of $\alpha 6$-integrin and CD71. Interestingly the effect on the expression of the stemness factors is differential, since while for SOX2 and NANOG the expression is higher in these cells, the opposite effect is observed for OCT4 (Fig. 3), suggesting that characterization of the E2 cells may not be so straightforward.

The modification in the expression level of these stemness factors could be related to the ability of HPV16-E2 protein to physically interact with several transcription factors such as CBP/p300, SP1, TAF1 and BRD4 $[33,65-68]$, all of them involved in the regulation of crucial genes for proliferation and differentiation 
pathways, and also in the regulation of SOX2, NANOG and OCT4 expression [56, 61]. As an example, it has been demonstrated that BRD4 is a very important piece in the regulation of NANOG gene expression [68], and the well known capability of HPV16-E2 to stabilize the binding of BRD4 to cellular promoters [69] could explain the overexpression observed in cells where HPV16-E2 is present. On the other side, it has been reported that SP1 factor binds directly to the OCT4 promoter favoring its transcription [70]. In this way, the physical interaction of E2 protein with SP1 [71, 72] could prevent its union to several gene promoters, OCT4 among them, explaining the low expression level of this factor observed in our assays.

The changes generated in the expression pattern of the stemness genes in the progenitor cells in HaCaT-HPV16$E 2$, suggest that the viral protein has a similar effect than the previously described for differentiation inducer agents [73-76]. Conditions previously reported for stimulation of differentiation in $\mathrm{HaCaT}$ cells with $\mathrm{CaCl}_{2}$ or RA [77, 78], caused a similar effect on the subpopulations profile to that observed in $\mathrm{HaCaT}$ cells expressing HPV16-E2 (Fig. 4, panels $c, d$ and $f$ ), confirming that this viral protein by itself is capable to induce a differentiation process. Until our knowledge, the effect of these differentiation inducers agents on the cellular subpopulations constituents of this cell line, has not been reported, then the present work is pioneering in this respect.

RA treatment of HaCaT-HPV16-E2 cells generated the apparent acceleration in the differentiation process, since the majority of cells in the total population corresponded to those committed to early differentiation (Fig. 4, panel g). However, $\mathrm{CaCl}_{2}$ treatment generated a profile where almost $70 \%$ of the cells corresponded to the transitory amplifying subpopulation. This means that in cells expressing HPV16-E2, the stimulus induces initially an accelerated proliferation process, and then cell differentiation (Fig. 4, panel e). This behavior could be explained by an increase in the activity of the cip/ kip family member $\mathrm{p} 21$, since it has been demonstrated that this gene is transcriptionally activated by HPV16E2 protein [33, 71, 79], and also by the cascade S100C/ A11 directly induced by $\mathrm{CaCl}_{2}$, leading the cells to hyperproliferation [77]. The same observed behavior could be also related to the expression or the absence of different regulators of the epidermal differentiation, such as the insulin growth factor binding protein 3 (IGFBP-3), which is characteristically expressed in cells from the epithelial basal layer and the repression of this factor by $\mathrm{CaCl}_{2}$ stimulus, leads cells to proliferation [80]. Interestingly, the effect of either $\mathrm{CaCl}_{2}$ or $\mathrm{RA}$ treatment on the relative abundance of the progenitor subpopulation in HaCaT-HPV16-E2 cells was radically different than the observed in $\mathrm{HaCaTwt}$ cells, inducing an increase and reaching $0.98 \%$ for RA and $1.38 \%$ for
$\mathrm{CaCl}_{2}$ induction (Fig. 4, panels d, e, $\mathrm{f}$ and g). This comportment generated by E2 expression could be due to both, the direct transcriptional regulation of genes involved in particular pathways, as well as to indirect mechanisms at epigenetic level, in genic regions that regulate cell fate decision to stemness or to differentiation.

Taken together these results suggest that the synergy between the differentiation stimulus that represents the expression of HPV16-E2 accompanied of a second differentiation stimulus such as $\mathrm{CaCl}_{2}$ or RA (HPV16-E2/ $\mathrm{CaCl}_{2}$ and HPV16-E2/AR) can promote the exit of some of the "progenitor cells" to the next immediate higher differentiation level, while the remaining percentage of this subpopulation is apparently less receptive to the stimulus, giving to these cells the opportunity to stays in a stemness status. These effects could guarantee the continuation of the replicative cycle that depends of the epithelial differentiation, besides the preservation of a small amount of progenitor cells ensuring the viral persistence.

\section{Conclusions}

In summary, we determined that $\mathrm{HaCaT}$ cell line possess three subpopulations that correspond to early differentiated, transitory amplifying and early progenitor cells. This latter population fully accomplishes the stem-like characteristics, such as enrichment, self-renewal, regeneration of the total population and expression of the stemness factors NANOG, SOX2 and OCT4. The HPV16-E2 expression modifies the relative abundance of the subpopulations, and affects the expression of the stemness factors. These changes could be involved in the control of the exit from stemness to transitory amplified cells or early differentiated cells. Further research on the effects of HPV16E2 expression and the differentiation pathways it regulates is needed.

\section{Additional file}

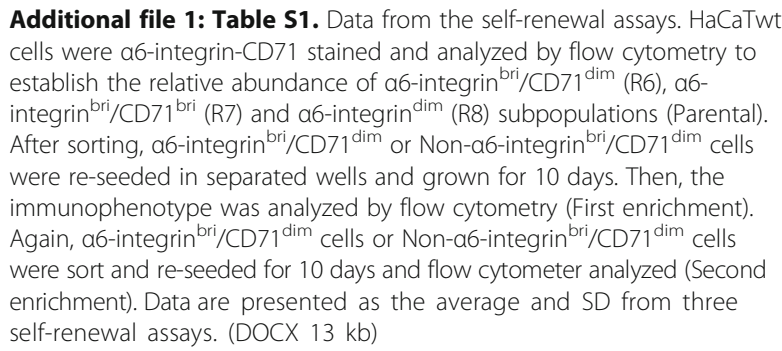

Additional file 1: Table S1. Data from the self-renewal assays. HaCaTwt cells were a6-integrin-CD71 stained and analyzed by flow cytometry to establish the relative abundance of a6-integrin ${ }^{\text {bri }} / \mathrm{CD} 1^{\mathrm{dim}}$ (R6), a6integrin $^{\text {bri }} /$ CD71 ${ }^{\text {bri }}$ (R7) and a6-integrin ${ }^{\text {dim }}$ (R8) subpopulations (Parental). After sorting, a6-integrin ${ }^{\text {bri }} / C D 71^{\text {dim }}$ or Non-a6-integrin ${ }^{\text {bri }} / C D 71^{\text {dim }}$ cells were re-seeded in separated wells and grown for 10 days. Then, the immunophenotype was analyzed by flow cytometry (First enrichment).

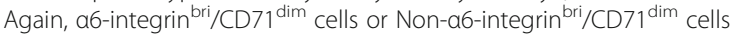
were sort and re-seeded for 10 days and flow cytometer analyzed (Second enrichment). Data are presented as the average and SD from three self-renewal assays. (DOCX $13 \mathrm{~kb}$ )

\section{Abbreviations}

${ }^{\circ} \mathrm{C}$ : Degrees Celsius; ABCG: ATP binding cassette subfamily G; ALDH: Aldehyde-dehydrogenase enzyme; bp: Base pairs; bri: Bright; BSA: Bovine serum albumin; $\mathrm{CaCl}_{2}$ : Calcium chloride; cDNA: Complementary DNA; Cts: Cycle thresholds; DMEM: Dulbecco's modified Eagle's medium; DNA: Deoxyribonucleic acid; EDTA: Ethylenediaminetetraacetic acid; EF1a: Elongation factor 1-a; FACS: Fluorescence activated cell sorting; FBS: Fetal 
bovine serum; Fig.: Figure; Fw: Forward; $\mathrm{HaCaTwt:} \mathrm{HaCaT}$ wild type; HPV: Human papillomavirus; h: Hours; IGFBP-3: Insulin growth factor binding protein 3; LCR: Long control region; Lenti-HPV16-E2: HPV16-E2 lentivirus; Lenti-Vac: Empty lentivirus; min: Minutes; ml: Milliliters; mM: Millimolar; MMLV RT: Moloney murine leukemia virus reverse transcriptase; MOI: Multiplicity of infection; NaCl: Sodium chloride; PBS: Phosphate-buffered saline; PCR: Polymerase chain reaction; PE: Phycoerythrin; qPCR: Real-time polymerase chain reaction; RA: Retinoic acid; Rev: Reverse; RIPA: Radioimmunoprecipitation assay; RNA: Ribonucleic acid; rpm: Revolutions per minute; RT: Reverse transcription; SD: Standard deviation; SDS-PAGE: Sodium dodecyl sulfate polyacrylamide gel electrophoresis; $\mu \mathrm{g}:$ Micrograms; $\mu$ l: Microlites; $\mu \mathrm{M}$ : Micromolar

\section{Acknowledgements}

We gratefully acknowledge Pedro Chavez for helpful technical assistance and Victor Rosales, Dr. Jairo Villanueva Toledo and M Sc. Alberto Ponciano Gómez for technical support in the lentivirus production, flow cytometer methods and data analysis.

\section{Funding}

This work was supported by grants from CONACyT (projects No. 105174 and 256514). VDC, AMRE and JSR received scholarships from CONACyT (166970, 234020 and 228869, respectively).

\section{Availability of data and materials}

Not applicable.

\section{Authors' contributions}

EG and VDC conceived and designed the study; VDC, AMRE, JSR, RCC and DLH performed the experiments and collected the data; EG and VDC performed the analysis and interpretation of data, and wrote the manuscript. All authors read and approved the final version of the manuscript.

\section{Competing interests}

The authors declare that they have no competing interests.

\section{Consent for publication}

Not applicable.

Ethics approval and consent to participate

Not applicable.

\section{Publisher's Note}

Springer Nature remains neutral with regard to jurisdictional claims in published maps and institutional affiliations.

\section{Received: 14 December 2016 Accepted: 23 March 2017} Published online: 03 April 2017

\section{References}

1. Egawa N, Egawa K, Griffin H, Doorbar J. Human papillomaviruses; epithelia tropisms, and the development of neoplasia. Viruses. 2015;7:3863-90.

2. de Villiers EM. Cross-roads in the classification of papillomaviruses. Virology. 2013:445:2-10.

3. Doorbar J, Quint W, Banks L, Bravo IG, Stoler M, Broker TR, Stanley MA. The biology and life-cycle of human papillomaviruses. Vaccine. 2012;30 Suppl 5:F55-70.

4. Doorbar J. Molecular biology of human papillomavirus infection and cervical cancer. Clin Sci (Lond). 2006;110:525-41.

5. Hegde RS. The papillomavirus e2 proteins: Structure, function, and biology. Annu Rev Biophys Biomol Struct. 2002;31:343-60.

6. Kim K, Garner-Hamrick PA, Fisher C, Lee D, Lambert PF. Methylation patterns of papillomavirus DNA, its influence on e2 function, and implications in viral infection. J Virol. 2003;77:12450-9.

7. McPhillips MG, Ozato K, McBride AA. Interaction of bovine papillomavirus e2 protein with brd4 stabilizes its association with chromatin. J Virol. 2005;79:8920-32.

8. McBride AA. The papillomavirus e2 proteins. Virology. 2013:445:57-79.

9. Ustav M, Stenlund A. Transient replication of bpv-1 requires two viral polypeptides encoded by the e 1 and e2 open reading frames. EMBO J. 1991;10:449-57.
10. Taylor ER, Morgan IM. A novel technique with enhanced detection and quantitation of hpv-16 e1- and e2-mediated DNA replication. Virology. 2003;315:103-9.

11. Gauson EJ, Donaldson MM, Dornan ES, Wang X, Bristol M, Bodily JM, Morgan IM. Evidence supporting a role for topbp1 and brd4 in the initiation but not continuation of human papillomavirus 16 e1/e2mediated DNA replication. J Virol. 2015;89:4980-91.

12. Akgul B, Pfefferle R, Marcuzzi GP, Zigrino P, Krieg T, Pfister H, Mauch C Expression of matrix metalloproteinase ( $\mathrm{mmp}$ )-2, mmp-9, mmp-13, and $\mathrm{mt1-mmp}$ in skin tumors of human papillomavirus type 8 transgenic mice. Exp Dermatol. 2006;15:35-42

13. Behren A, Simon C, Schwab RM, Loetzsch E, Brodbeck S, Huber E, Stubenrauch F, Zenner HP, Iftner T. Papillomavirus e2 protein induces expression of the matrix metalloproteinase- 9 via the extracellular signalregulated kinase/activator protein-1 signaling pathway. Cancer Res. 2005;65:11613-21.

14. Bermudez-Morales VH, Peralta-Zaragoza O, Alcocer-Gonzalez JM, Moreno J, Madrid-Marina V. II-10 expression is regulated by hpv e2 protein in cervical cancer cells. Mol Med Rep. 2011:4:369-75.

15. Gasparian AV, Fedorova MD, Kisselev FL. Regulation of matrix metalloproteinase-9 transcription in squamous cell carcinoma of uterine cervix: The role of human papillomavirus gene e2 expression and activation of transcription factor nf-kappab. Biochemistry (Mosc). 2007;72:848-53.

16. Lee D, Kim HZ, Jeong KW, Shim YS, Horikawa I, Barrett JC, Choe J. Human papillomavirus e2 down-regulates the human telomerase reverse transcriptase promoter. J Biol Chem. 2002;277:27748-56.

17. Mole S, Milligan SG, Graham SV. Human papillomavirus type 16 e2 protein transcriptionally activates the promoter of a key cellular splicing factor, sf2/ asf. J Virol. 2009;83:357-67.

18. Muhlen S, Behren A, Iftner T, Simon C. Influence of hpv16 e2 and its localisation on the expression of matrix metalloproteinase-9. Int J Oncol. 2010;37:337-45.

19. Oldak M, Maksym RB, Sperling T, Yaniv M, Smola H, Pfister HJ, Malejczyk J, Smola S. Human papillomavirus type 8 e2 protein unravels junb/fra-1 as an activator of the beta4-integrin gene in human keratinocytes. J Virol. 2010;84:1376-86.

20. Ramirez-Salazar E, Centeno F, Nieto K, Valencia-Hernandez A, Salcedo M, Garrido E. Hpv16 e2 could act as down-regulator in cellular genes implicated in apoptosis, proliferation and cell differentiation. Virol J. 2011:8:247.

21. Webster K, Parish J, Pandya M, Stern PL, Clarke AR, Gaston K. The human papillomavirus (hpv) $16 \mathrm{e} 2$ protein induces apoptosis in the absence of other hpv proteins and via a p53-dependent pathway. J Biol Chem. 2000;275:87-94.

22. Burns JE, Burn CL, Hernandez-Ramon EE, Schmitz C, Lloansi Vila A, Maitland NJ. Forms and functions of papillomavirus e2 proteins. Recent Res Dev Biochem. 2003;4:795-823.

23. Dowhanick JJ, McBride AA, Howley PM. Suppression of cellular proliferation by the papillomavirus e2 protein. J Virol. 1995;69:7791-9.

24. Goodwin EC, Naeger LK, Breiding DE, Androphy EJ, DiMaio D. Transactivation-competent bovine papillomavirus e2 protein is specifically required for efficient repression of human papillomavirus oncogene expression and for acute growth inhibition of cervical carcinoma cell lines. J Virol. 1998;72:3925-34.

25. Hwang ES, Riese 2nd DJ, Settleman J, Nilson LA, Honig J, Flynn S, DiMaio D. Inhibition of cervical carcinoma cell line proliferation by the introduction of a bovine papillomavirus regulatory gene. J Virol. 1993;67:3720-9.

26. Moon MS, Lee CJ, Um SJ, Park JS, Yang JM, Hwang ES. Effect of bpv1 e2mediated inhibition of e6/e7 expression in hpv16-positive cervical carcinoma cells. Gynecol Oncol. 2001;80:168-75.

27. Naeger LK, Goodwin EC, Hwang ES, DeFilippis RA, Zhang H, DiMaio D. Bovine papillomavirus e2 protein activates a complex growth-inhibitory program in p53-negative ht-3 cervical carcinoma cells that includes repression of cyclin a and cdc25a phosphatase genes and accumulation of hypophosphorylated retinoblastoma protein. Cell Growth Differ. 1999;10:413-22.

28. Demeret C, Garcia-Carranca A, Thierry F. Transcription-independent triggering of the extrinsic pathway of apoptosis by human papillomavirus 18 e2 protein. Oncogene. 2003;22:168-75.

29. Thierry F, Demeret C. Direct activation of caspase 8 by the proapoptotic e2 protein of hpv18 independent of adaptor proteins. Cell Death Differ. 2008; 15:1356-63.

30. Goodwin EC, DiMaio D. Repression of human papillomavirus oncogenes in hela cervical carcinoma cells causes the orderly reactivation of dormant tumor suppressor pathways. Proc Natl Acad Sci U S A. 2000;97:12513-8. 
31. Johung K, Goodwin EC, DiMaio D. Human papillomavirus e7 repression in cervical carcinoma cells initiates a transcriptional cascade driven by the retinoblastoma family, resulting in senescence. J Virol. 2007:81:2102-16.

32. Kang HT, Lee CJ, Seo EJ, Bahn YJ, Kim HJ, Hwang ES. Transition to an irreversible state of senescence in hela cells arrested by repression of hpv e6 and e7 genes. Mech Ageing Dev. 2004;125:31-40.

33. Wells SI, Francis DA, Karpova AY, Dowhanick JJ, Benson JD, Howley PM. Papillomavirus e2 induces senescence in hpv-positive cells via prb- and p21(cip)-dependent pathways. EMBO J. 2000;19:5762-71.

34. Burns JE, Walker HF, Schmitz C, Maitland NJ. Phenotypic effects of hpv-16 e2 protein expression in human keratinocytes. Virology. 2010;401:314-21.

35. Wright WE, Shay JW. The two-stage mechanism controlling cellular senescence and immortalization. Exp Gerontol. 1992;27:383-9.

36. Arroyo M, Bagchi S, Raychaudhuri P. Association of the human papillomavirus type 16 e7 protein with the s-phase-specific e2f-cyclin a complex. Mol Cell Biol. 1993;13:6537-46.

37. Matlashewski G. The cell biology of human papillomavirus transformed cells. Anticancer Res. 1989;9:1447-56.

38. Suh DS, Kim SC, An WG, Lee CH, Choi KU, Song JM, Jung JS, Lee KS, Yoon MS. Differential apoptotic response in hpv-infected cancer cells of the uterine cervix after doxorubicin treatment. Oncol Rep. 2010;23:751-6.

39. Fusenig NE, Boukamp P. Multiple stages and genetic alterations in immortalization, malignant transformation, and tumor progression of human skin keratinocytes. Mol Carcinog. 1998;23:144-58.

40. Javaherian A, Vaccariello M, Fusenig NE, Garlick JA. Normal keratinocytes suppress early stages of neoplastic progression in stratified epithelium Cancer Res. 1998;58:2200-8.

41. Yirrell DL, Roome AP, Darville JM, Ashley CR, Harbour J. Comparison of the continuous cell line 293 with human embryo kidney cells and human embryo fibroblast cells for the cultivation of ocular viruses. J Clin Pathol. 1983;36:996-9.

42. Ozbun MA. Human papillomavirus type 31b infection of human keratinocytes and the onset of early transcription. J Virol. 2002;76:11291-300.

43. Klumpp DJ, Laimins LA. Differentiation-induced changes in promoter usage for transcripts encoding the human papillomavirus type 31 replication protein e1. Virology. 1999;257:239-46.

44. Gilormini M, Wozny AS, Battiston-Montagne P, Ardail D, Alphonse G, Rodriguez-Lafrasse C. Isolation and characterization of a head and neck squamous cell carcinoma subpopulation having stem cell characteristics. J Vis Exp. 2016;11:e53958.

45. Ortiz-Sanchez E, Santiago-Lopez L, Cruz-Dominguez VB, Toledo-Guzman ME, Hernandez-Cueto D, Muniz-Hernandez S, Garrido E, Cantu-De Leon D, Garcia-Carranca A. Characterization of cervical cancer stem cell-like cells: Phenotyping, stemness, and human papilloma virus co-receptor expression. Oncotarget. 2016;7:31943-54

46. Villanueva-Toledo J, Ponciano-Gomez A, Ortiz-Sanchez E, Garrido E. Side populations from cervical-cancer-derived cell lines have stem-cell-like properties. Mol Biol Rep. 2014;41:1993-2004

47. Wan H, Yuan M, Simpson C, Allen K, Gavins FN, Ikram MS, Basu S, Baksh N, O'Toole EA, Hart IR. Stem/progenitor cell-like properties of desmoglein 3 dim cells in primary and immortalized keratinocyte lines. Stem Cells. 2007;25:1286-97.

48. Schluter H, Paquet-Fifield S, Gangatirkar P, Li J, Kaur P. Functional characterization of quiescent keratinocyte stem cells and their progeny reveals a hierarchical organization in human skin epidermis. Stem Cells. 2011;29:1256-68.

49. Pfaffl MW. A new mathematical model for relative quantification in real-time rt-pcr. Nucleic Acids Res. 2001;29:e45.

50. Pasquariello N, Oddi S, Malaponti M, Maccarrone M. Regulation of gene transcription and keratinocyte differentiation by anandamide. Vitam Horm. 2009;81:441-67.

51. Kaur P, Li A. Adhesive properties of human basal epidermal cells: An analysis of keratinocyte stem cells, transit amplifying cells, and postmitotic differentiating cells. J Invest Dermatol. 2000;114:413-20.

52. Poumay Y, Herphelin F, Smits P, De Potter IY, Pittelkow MR. High-celldensity phorbol ester and retinoic acid upregulate involucrin and downregulate suprabasal keratin 10 in autocrine cultures of human epidermal keratinocytes. Mol Cell Biol Res Commun. 1999;2:138-44.

53. Denning MF, Dlugosz AA, Williams EK, Szallasi Z, Blumberg PM, Yuspa SH. Specific protein kinase $c$ isozymes mediate the induction of keratinocyte differentiation markers by calcium. Cell Growth Differ. 1995;6:149-57.
54. Boukamp P, Petrussevska RT, Breitkreutz D, Hornung J, Markham A, Fusenig NE. Normal keratinization in a spontaneously immortalized aneuploid human keratinocyte cell line. J Cell Biol. 1988;106:761-71.

55. Buschke S, Stark HJ, Cerezo A, Pratzel-Wunder S, Boehnke K, Kollar J, Langbein L, Heldin CH, Boukamp P. A decisive function of transforming growth factor-beta/smad signaling in tissue morphogenesis and differentiation of human hacat keratinocytes. Mol Biol Cell. 2011;22:782-94.

56. Tai MH, Chang CC, Kiupel M, Webster JD, Olson LK, Trosko JE. Oct4 expression in adult human stem cells: Evidence in support of the stem cell theory of carcinogenesis. Carcinogenesis. 2005;26:495-502.

57. Miyamoto T, Furusawa C, Kaneko K. Pluripotency, differentiation, and reprogramming: A gene expression dynamics model with epigenetic feedback regulation. PLoS Comput Biol. 2015;11:e1004476.

58. Liang S, Furuhashi M, Nakane R, Nakazawa S, Goudarzi H, Hamada J, lizasa $\mathrm{H}$. Isolation and characterization of human breast cancer cells with sox2 promoter activity. Biochem Biophys Res Commun. 2013;437:205-11.

59. Barrandon $Y$, Green $\mathrm{H}$. Three clonal types of keratinocyte with different capacities for multiplication. Proc Natl Acad Sci U S A. 1987;84:2302-6.

60. Li X, Upadhyay AK, Bullock AJ, Dicolandrea T, Xu J, Binder RL, Robinson MK, Finlay DR, Mills KJ, Bascom CC, Kelling CK, Isfort RJ, Haycock JW, MacNeil S, Smallwood RH. Skin stem cell hypotheses and long term clone survival_explored using agent-based modelling. Sci Rep. 2013;3:1904.

61. Chen Y, Sen GL. Sox2 expression inhibits terminal epidermal differentiation. Exp Dermatol. 2015;24:974-6.

62. Bikle DD, Xie Z, Tu CL. Calcium regulation of keratinocyte differentiation. Expert Rev Endocrinol Metab. 2012;7:461-72.

63. Deyrieux AF, Wilson VG. In vitro culture conditions to study keratinocyte differentiation using the hacat cell line. Cytotechnology. 2007:54:77-83.

64. Torma H. Regulation of keratin expression by retinoids. Dermatoendocrinol. 2011;3:136-40.

65. Centeno F, Ramirez-Salazar E, Garcia-Villa E, Gariglio P, Garrido E. Taf1 interacts with and modulates human papillomavirus 16 e2-dependent transcriptional regulation. Intervirology. 2008;51:137-43.

66. Hadaschik D, Hinterkeuser K, Oldak M, Pfister HJ, Smola-Hess S. The papillomavirus e2 protein binds to and synergizes with c/ebp factors involved in keratinocyte differentiation. J Virol. 2003;77:5253-65.

67. Helfer CM, Yan J, You J. The cellular bromodomain protein brd4 has multiple functions in e2-mediated papillomavirus transcription activation. Viruses. 2014;6:3228-49.

68. Horne GA, Stewart HJ, Dickson J, Knapp S, Ramsahoye B, Chevassut T. Nanog requires brd4 to maintain murine embryonic stem cell pluripotency and is suppressed by bromodomain inhibitor jq1 together with lefty1. Stem Cells Dev. 2015;24:879-91.

69. Jang MK, Kwon D, McBride AA. Papillomavirus e2 proteins and the host brd4 protein associate with transcriptionally active cellular chromatin. J Virol. 2009;83:2592-600.

70. Yang HM, Do HJ, Oh JH, Kim JH, Choi SY, Cha KY, Chung HM, Kim JH. Characterization of putative cis-regulatory elements that control the transcriptional activity of the human oct4 promoter. J Cell Biochem. 2005; 96:821-30.

71. Steger G, Schnabel C, Schmidt HM. The hinge region of the human papillomavirus type 8 e2 protein activates the human p21(waf1/cip1) promoter via interaction with sp1. J Gen Virol. 2002;83:503-10.

72. Li R, Knight JD, Jackson SP, Tjian R, Botchan MR. Direct interaction between sp1 and the bpv enhancer e2 protein mediates synergistic activation of transcription. Cell. 1991;65:493-505.

73. Kovacevic Grujicic N, Mojsin M, Krstic A, Stevanovic M. Functional characterization of the human sox3 promoter: Identification of transcription factors implicated in basal promoter activity. Gene. 2005;344:287-97.

74. Li X, Li L, Pandey R, Byun JS, Gardner K, Qin Z, Dou Y. The histone acetyltransferase mof is a key regulator of the embryonic stem cell core transcriptional network. Cell Stem Cell. 2012;11:163-78.

75. Miyanari $Y$, Torres-Padilla ME. Control of ground-state pluripotency by allelic regulation of nanog. Nature. 2012;483:470-3.

76. Rodda DJ, Chew JL, Lim LH, Loh YH, Wang B, Ng HH, Robson P. Transcriptional regulation of nanog by oct4 and sox2. J Biol Chem. 2005;280:24731-7.

77. Micallef L, Belaubre F, Pinon A, Jayat-Vignoles C, Delage C, Charveron M, Simon A. Effects of extracellular calcium on the growth-differentiation switch in immortalized keratinocyte hacat cells compared with normal human keratinocytes. Exp Dermatol. 2009;18:143-51. 
78. Xing $F$, Liao $W$, Jiang $P$, Xu W, Jin X. Effect of retinoic acid on aquaporin 3 expression in keratinocytes. Genet Mol Res. 2016;15:15016951.

79. Prabhavathy D, Subramanian CK, Karunagaran D. Re-expression of hpv16 e2 in siha (human cervical cancer) cells potentiates nf-kappab activation induced by tnf-alpha concurrently increasing senescence and survival. Biosci Rep. 2015;35:e00175.

80. Edmondson SR, Werther GA, Wraight CJ. Calcium regulates the expression of insulin-like growth factor binding protein-3 by the human keratinocyte cell line hacat. J Invest Dermatol. 2001;116:491-7.

Submit your next manuscript to BioMed Central and we will help you at every step:

- We accept pre-submission inquiries

- Our selector tool helps you to find the most relevant journal

- We provide round the clock customer support

- Convenient online submission

- Thorough peer review

- Inclusion in PubMed and all major indexing services

- Maximum visibility for your research

Submit your manuscript at www.biomedcentral.com/submit
Biomed Central 